\title{
Eko-filozofia a perspektywa ekologicznego konserwatyzmu
}

\author{
Eco-philosophy and the Perspective of Ecological Conservatism
}

\author{
Mikołaj Niedek \\ Narodowy Instytut Kultury i Dziedzictwa Wsi \\ ORCID: https://orcid.org/0000-0001-5241-5150•mikolaj.niedek@nikidw.edu.pl \\ Zgłoszono: 5.01.2021; zrecenzowano: 25.02.2021; zaakceptowano do druku: 4.03.2021
}

\begin{abstract}
Streszczenie: Niniejszy artykuł przedstawia stanowiska ekofilozoficzne prezentowane przez Henryka Skolimowskiego, Rogera Scrutona i papieża Franciszka w ich zapatrywaniach na kwestie problematyki ekologicznej. Dotyczy to zarówno diagnozowanych przyczyn współczesnego kryzysu ekologicznego, jak i konstruktywnych propozycji przeciwdziałania jemu poprzez zmianę naszego sposobu myślenia i postawy względem świata. Artykuł rozpoczyna się od zarysowania początków filozofii ekologicznej i jej definiowania jako refleksji światopoglądowej nad relacją człowieka wobec środowiska. Uwagę autora skupia ideowy profil koncepcji ekofilozoficznych, który wyznacza progresywny lub konserwatywny światopogląd stojący u podstaw danej ekofilozofii. Zdaniem autora zieloną filozofię R. Scrutona i koncepcję ekologii integralnej papieża Franciszka można zakwalifikować do ekologicznego konserwatyzmu. Eko-filozofia H. Skolimowskiego pozwala natomiast koncepcyjnie zapośredniczyć zarówno progresywne, jak i konserwatywne propozycje ekofilozoficzne. Zdaniem autora ważna jest świadomość zarówno różnic, jak i podobieństw różnych ekofilozofii. Wspólnym elementem analizowanych w artykule koncepcji jest znaczenie proekologicznego, przyjaznego środowisku stylu życia dla przeciwdziałania kryzysowi ekologicznemu.
\end{abstract}

Słowa kluczowe: eko-filozofia, ekofilozofia, Henryk Skolimowski, zielona filozofia Rogera Scrutona, ekologia integralna papieża Franciszka

\begin{abstract}
This article presents eco-philosophical approaches and ideas presented by Henryk Skolimowski, Roger Scruton, and Pope Francis, in their views on environmental issues. This applies both to the diagnosed causes of the contemporary ecological crisis and constructive proposals to counteract this crisis, by changing our way of thinking and attitudes towards the world. The article begins with an outline of the beginnings of ecological philosophy as a worldview reflection on the relationship of man to the environment. The author's attention is focused on the ideological profile of eco-philosophical concepts, which determines the progressive or conservative profile of a given eco-philosophy. In the author's opinion, the green philosophy of R. Scruton, as well as the concept of integral ecology by Pope Francis, can both be classified as ecological conservatism. The eco-philosophy of H. Skolimowski, on the other hand, makes it possible to mediate both progressive and conservative eco-philosophical proposals. According to the author, it is important to be aware of both the differences and the similarities of various eco-philosophies. The common element of the concepts, analysed in the article, is the importance of an ecological, environmentally friendly lifestyle for counteracting the ecological crisis.
\end{abstract}

Keywords: eco-philosophy, Henryk Skolimowski, Roger Scruton's green philosophy, Pope Francis's integral ecology 


\section{Wprowadzenie}

Celem niniejszego artykułu jest zarys głównych idei filozofii ekologicznej Henryka Skolimowskiego na tle propozycji ideowych sformułowanych w proekologicznych koncepcjach Rogera Scrutona i papieża Franciszka. W artykule postawiona została teza, że możliwy jest ekologiczny konserwatyzm, a przykładem filozofii ekologicznych formułowanych na gruncie konserwatywnego systemu wartości są koncepcje wspomnianych autorów. Eko-filozofii ${ }^{1}$ Henryka Skolimowskiego nie da się jednoznacznie zakwalifikować do nurtu konserwatywnego czy progresywnego. Dzięki temu może ona stanowić koncepcyjną przestrzeń zapośredniczającą te dwie odmienne perspektywy, stwarzając miejsce do nieantagonistycznego dialogu i wypracowania bazy wspólnych i jednoczących wartości ekologicznych.

Ekofilozofia jest filozofią nieanalityczną i światopoglądową, nieograniczającą się do kwestii językowych i historyczno-filozoficznych, jak ma to miejsce w przypadku filozofii analitycznej i akademickiej. Jest filozofią zaliczaną często do nurtu filozofii życia, zdecydowanie odmienną jednak od egzystencjalizmu². Równolegle do rozważań filozoficznych nad kwestiami ekologicznymi prowadzona jest refleksja moralna nad stosunkiem człowieka do środowiska i innych istot żywych, ujmowana w ramach etyki środowiskowej (Bonenberg 1992). Na potrzeby niniejszego wywodu przyjmuję, że filozofia ekologiczna, to koncepcje filozoficzne tworzone przez różnych autorów na gruncie różnych perspektyw ideowych i aksjologicznych, mające na celu określenie przyczyn współczesnego kryzysu ekologicznego i sformułowanie propozycji przeciwdziałania jemu, w tym zasad etycznych. Według

1 Konwencję terminologiczną, by na oznaczenie ekofilozofii H. Skolimowskiego stosować konsekwentnie zapis „eko-filozofia” (z myślnikiem), zaproponował A. Papuziński (Papuziński i Hull 2001).

${ }^{2}$ Wyjątkiem może tu być filozofia M. Heideggera, zaliczanego zazwyczaj do filozofów egzystencji, którego filozofia Bycia zawiera wiele prekursorskich dla ekofilozofii idei (Hoły-Łuczaj 2018).
H. Skolimowskiego filozofia ekologiczna (eko-filozofia) „zajmuje się systematycznym wyciąganiem konsekwencji z założenia, że świat jest sanktuarium" (Skolimowski 1999).

\section{Profil ideowy ekofilozofii}

Henryk Skolimowski (1930-2018) jest twórcą filozofii ekologicznej, określanej mianem eko-filozofii. Za jej początek uznaje się opublikowanie przezeń artykuł pt. Ecological Humanism (Skolimowski 1977, gdzie - jak sam twierdził - zawarł główne idee swojej przyszłej filozofii, w tym jej naczelna ideę świata jako sanktuarium (The World as Sanctuary). Obok eko-filozofii w latach 70. XX w. powstały różne inne koncepcje filozofii ekologicznej, a wiele z nich rozwinęło się w rozbudowane systemy. Przykładem może być ekologia głęboka stworzona przez norweskiego filozofa Arne Naess'a, Bill Devalla i Georges'a Sessions'a; ekologia społeczna Murray'a Bookchina, nowa opowieść o Ziemi Thomasa Berry'ego czy ekofeminizm zapoczątkowany przez Françoise d'Eaubonne ${ }^{3}$. Należy wszakże odróżnić filozofię ekologiczną, z jednej strony, od ruchu New Age noszącego znamiona ideologii, z drugiej zaś od filozofii ekologii mającej charakter akademicki i naukowy (Papuziński 1999). Jako dyscyplina poznawcza stanowi ona, obok ekopsychologii, ekonomii ekologicznej, środowiskowo zorientowanej socjologii oraz polityki ekologicznej, obszar zainteresowania szeroko pojętej ekologii społecznej (Kiełczewski 2001). Asumptem do rozwoju refleksji ekofilozoficznej była rosnąca świadomość zagrożeń związanych z ekspansją cywilizacji przemysłowej i jej negatywnym oddziaływaniem na środowisko oraz system życia biosfery, z których sprawę zdawały raporty nt. globalnego stanu środowiska: raport Sekretarza ONZ U Thanta (Thant 1969), raporty Klubu Rzymskiego (Meadows et al. 1972), raport G.H. Brundtland Nasza wspólna przyszłość (Brundtland

3 Kompleksowego przeglądu i charakterystyki stanowisk ekofilozoficznych XX w. dokonał D. Kiełczewski w pracy Ekologia społeczna (Kiełczewski 2001). 
1987). Raporty te prezentowały empiryczny obraz stanu środowiska, stwarzając podstawy i wytyczne do wypracowania koncepcji trwałego i zrównoważonego rozwoju (sustainable development), w wymiarze globalnym sformułowanej w dokumencie Agenda 21 przyjętym na Szczycie Ziemi ONZ w Rio de Janeiro w 1992 r., a następnie w Planie Działania przyjętym na Światowym Szczycie Zrównoważonego Rozwoju w Johannesburgu w 2002 r.

Refleksja i koncepcje ekofilozoficzne w drugiej połowie XX w. powstawały głównie na gruncie światopoglądów niekonserwatywnych, lewicujących. Czołowy krytyk filozofii ekologicznej, Luc Ferry, zasadniczo w jej radyklanej wersji biocentrycznego egalitaryzmu akcentuje wszakże antecedencje ekofilozofii w ideologii ruchu narodowo-socjalistycznego III Rzeszy, czego przykładem jest volkizm (Ferry 1995). Zasadność tego zarzutu zależy od rozstrzygnięcia, czy niemiecki nazizm (narodowy socjalizm) miał bardziej charakter narodowy (prawicowy) czy też socjalistyczny (lewicowy). Warto zauważyć, że Ferry już w XXI w. stwierdził, że problematyka środowiskowa i idee ekologiczne są jedynymi zasadniczo nowymi, ale i najważniejszymi ideami, jakie powstały w filozofii XX w. (Ferry and Capelier 2016). Za pioniera ruchu ochrony środowiska w Polsce uznaje się związanego z endecją Jana Gwalberta-Pawlikowskiego. Jednym z założycieli powojennego, niemieckiego ruchu Zielonych był konserwatysta Herbert Gruhl (Gruhl 1976). Ruch polskich Zielonych wyrastał również z solidarnego ducha sprzeciwu w odniesieniu do niszczycielskich wobec środowiska i przyrody zapędów komunistycznej władzy ludowej okresu PRL (Gliński 1994). Choć antecedencje idei ekofilozoficznych można wyczytać w pracach wielu autorów niezwiązanych z lewicą, pierwsze i rozbudowane światopoglądy i systemy ekofilozoficzne powstały na gruncie progresywno-lewicowym, wyartykułowanym ideowo w XX w. w ruchu tzw. Nowej Lewicy i działalności Szkoły frankfurckiej.
W powszechnej opinii spójny i konsekwentny światopogląd ekologiczny, domagający się proekologicznej rewolucji i przemiany całej cywilizacji współczesnej, możliwy jest wyłącznie na gruncie progresywnego (lewicowego) systemu wartości, gdyż na gruncie światopoglądu konserwatywnego, dążącego generalnie do zachowania status quo, byłby on wewnętrznie sprzeczny. Przykładowo, w publicystycznej wypowiedzi Agnieszka Kołakowska stwierdziła, że ekologiczny konserwatyzm jest niemożliwy, a każda forma ekologizmu z założenia ma charakter lewicowy: „Tak więc zielony konserwatysta ma kłopot, bo nie może istnieć. Nie ma mowy o sojuszach z zielonymi, nawet w najbardziej niewinnie brzmiącej sprawie; takie sojusze zawsze źle się kończą - tak samo, jak źle się kończą próby ocalenia świata. Co jednak nie przeszkadza w popieraniu - bez żadnych sojuszy - poszczególnych, konkretnych inicjatyw, dążących, na przykład, do skutecznego (i unikającego niepożądanych skutków) chronienia tygrysów czy słoni, czy zielonych obszarów. (Dla konserwatysty zwierzęta wprawdzie nie mają praw, ale ludzie mają wobec nich obowiązki. Poza tym świat, w którym są słonie i tygrysy, jest lepszy od świata, w którym ich nie ma.) Konserwatysta, będąc praktycznie nastawiony i skupiając się nad konkretnymi możliwościami na swoim małym skrawku, pozostanie w całkowitej zgodzie ze swoimi zasadami i swoim podejściem, jeśli poprze, na przykład, humanitarne traktowanie kurczaków (dla zdrowia zarazem ich i naszego), zakazy hodowli zwierząt futerkowych i inne kojarzone na ogół z lewicą inicjatywy. Nie tylko może, lecz nawet powinien takie rzeczy popierać, by zapobiec ich uzurpacji przez zielonych i przekształceniu w kolejny polityczny ruch" (Kołakowska 2018).

Nie zgadzając się ze stanowiskiem Kołakowskiej, przyjmuję tezę, iż możliwa jest filozofia ekologiczna na gruncie konserwatywnego systemu wartości, a jej przykładem jest zielona filozofia znanego filozofa konserwatyzmu Rogera Scrutona (Scruton 
2017). Do prawej, konserwatywnej strony należy również zaliczyć koncepcję ekologii integralnej, sformułowanej przez papieża Franciszka i wyłożonej w encyklice Laudato si' (Franciszek 2015). Koncepcja ta, co oczywiste, sformułowana została na gruncie katolickiej filozofii chrześcijańskiej, mającej charakter religijno-konserwatywny.

Filozofię ekologiczną Henryka Skolimowskiego trudno jednoznacznie zakwalifikować do progresywnych lub konserwatywnych nurtów filozoficznych. Przedstawię dalej główne idee jego eko-filozofii w porównaniu do zapatrywań na kwestie ekologiczne, sformułowanych przez R. Scrutona i papieża Franciszka. Tezą, jaką tu stawiam na gruncie przeprowadzonych analiz filozofii ekologicznej H. Skolimowskiego, jak również wieloletniej znajomości jego osoby i głoszonych przezeń poglądów, jest stwierdzenie, że eko-filozofia H. Skolimowskiego ma charakter uniwersalistyczny i może stanowić koncepcyjną przestrzeń zapośredniczającą zarówno progresywne, jak i konserwatywne ujęcie problematyki ekologicznej.

\section{Główne założenia i idee eko-filozofii H. Skolimowskiego}

Henryk Skolimowski urodził się w maju 1930 r. w Warszawie. Ukończył Politechnikę Warszawską (geodezja) i Uniwersytet Warszawski, gdzie uzyskał w 1959 r. magisterium z filozofii. Był uczniem W. Tatarkiewicza, T. Kotarbińskiego, K. Ajdukiewicza. Doktorat uzyskał w 1964 r. na Uniwersytecie w Oksfordzie, po czym wyemigrował do USA. Wykładał na Uniwersytecie Południowej Kalifornii (1964-1970) oraz na Uniwersytecie Michigan w Ann Arbor (1971-1993). Do Polski powrócił na początku lat 9o., propagując idee swojej eko-filozofii. Był inicjatorem pierwszej na świecie katedry ekofilozofii na Politechnice Łódzkiej, utworzonej w 1992 r. Opublikował ponad 30 książek, tłumaczonych na kilkanaście języków oraz kilkuset artykułów. W 2015 r. został uhonorowany medalem Optime Meritis de Philosophia przyznanym na X Polskim Zjeździe Filozoficznym dla najwybitniejszych filozofów polskich XX wieku. Zmarł w kwietniu 2018 r. w Świdrze.

H. Skolimowski wywodził się z analitycznego nurtu filozofii polskiej, a swój doktorat poświęcił jej porównaniu z filozofią brytyjską (Skolimowski 1967). Przedmiotem jego zainteresowań w trakcie działalności akademickiej na uczelniach amerykańskich była filozofia nauki i techniki. W swojej działalności naukowej pozostawał pod wpływem Carla R. Poppera, którego wykładów był słuchaczem. Publikacją zapowiadającą krytyczny zwrot wobec filozofii analitycznej, jak i generalną krytykę zachodniej cywilizacji naukowo-technicznej była książka Zmierzch światopogladu naukowego (Skolimowski 1974). Na ukształtowanie się światopoglądu ekofilozoficznego H. Skolimowskiego znaczący wpływ wywarły: lektury Pierre'a T. de Chardin'a i jego wizja teleologicznej ewolucji kosmicznej, zasada antropiczna formułowana przez filozofujących kosmologów oraz hipotezy stawiane przez posteinsteinowską fizykę, jak teoria ukrytego porządku Davida Bohm'a czy koncepcja wszechświata partycypującego Johna A. Wheeler'a. Wpływ wiedzy i odkryć nauk przyrodniczych, głównie nowej fizyki i kosmologii, na podstawy światopoglądowe eko-filozofii - mającej za przedmiot środowisko, naturę i jej relacje z człowiekiem - funduje jej interdyscyplinarność humanistyczno-przyrodniczą. W przypadku H. Skolimowskiego zaowocowało to stworzeniem eko-kosmologii, w której na obraz Świata i Kosmosu wpływają zasadniczo założenia, jakie przyjmujemy na ich temat. Mają one charakter przednaukowy, a nawet preepistemiczny (przedpoznawczy), kształtowany przez paradygmatyczną metaforę przyjmowaną a priori. Założenie to Skolimowski rozbudował w koncepcję umysłu partycypującego (Skolimowski 1995b).

W nowożytnym paradygmacie mechanistycznym, ufundowanym przez Francisa Bacona, Kartezjusza i Newtona kluczowa jest metafora zegara i obraz Kosmosu jako wielkiego mechanizmu rządzonego ścisłymi prawami. Paradygmat ten skutkował 
redukcjonistycznym obrazem świata, którego konsekwencją jest - według Skolimowskiego - właśnie współczesny kryzys ekologiczny. Mechanicyzm implikuje bowiem instrumentalną, manipulacyjną i eksploatacyjną postawę wobec świata, przyrody i ludzi, jak również wobec wiedzy i poznania, promując takie wartości, jak: skuteczność, efektywność, wydajność, praktyczność, kontrolowalność, obiektywizacja, uprzedmiotowienie, wymienialność, użyteczność, wykorzystanie i zużycie. Według Skolimowskiego wcieleniem tych wartości jest pozytywistyczna nauka oraz współczesna technika i technologia, w których instrumentalne podejście do świata, traktowanego jako zbiór zasobów i rzeczy, osiąga swoje apogeum. Odbywa się to kosztem rozwoju duchowego, kultury i wartości autotelicznych, a w konsekwencji skutkuje kryzysem ekologicznym będącym przejawem kryzysu relacji Człowieka ze Światem jako miejscem jego życia (Skolimowski 1995a). W ujęciu mechanistycznym Świat i cały byt traktowany jest jako zbiór elementów rządzonych przez deterministyczne prawa, a rzeczywistość społeczna przez sztywne i arbitralne normy.

Odmienny obraz świata kształtuje się przy założeniu, jakie przyjmuje eko-kosmologia, w której optyce Świat jawi się jako Sanktuarium - miejsce obecności Sacrum, wymagające szacunku i czci - rewerencji. Ten odmienny i przeciwstawny do mechanistycznego paradygmat, określany też mianem organicznego lub ekosystemowego (Najder-Stefaniak 2013) bazuje na nieinstrumentalnym podejściu do świata i uznaniu, że byty ożywione i nieożywione mają samoistną wartość, a właściwą postawą wobec nich jest postawa kontemplacji ich znaczeń i piękna oraz ich zachowanie dla przyszłych pokoleń (Skolimowski 1993). W paradygmacie ekosystemowym naczelną kategorię poznawczą stanowi pojęcie życia, systemu i rozwoju - ewolucji. Życie i System stanowią całości, których emergentna jakość jest niesprowadzalna do składających się na nią części. Rysem paradygmatu ekosystemowego jest więc holizm, obok którego ewolucyjna geneza i ewolucyjna przyszłość Człowieka, Życia, Świata i Kosmosu stanową bazę eko-filozofii. Za prekursorów swoich idei Skolimowski uważał filozofów procesu, życia i ewolucji: Alfreda N. Whiteheada, Henri Bergsona, Pierre'a T. de Chardin'a.

Budowę eko-filozofii Skolimowski rozpoczął od prześledzenia źródeł współczesnego kryzysu ekologicznego, lokując je w nowożytnym mechanicyzmie i dualizmie ontologicznym wprowadzonym przez Kartezjusza. Swym radykalnym racjonalizmem utrwalił on rozłam pomiędzy ciałem i duszą, duchem i materią, Bogiem i Światem, Człowiekiem i Przyrodą, podmiotem i przedmiotem. To fundamentalne, dualistyczne pęknięcie owocowało w dalszej historii filozofii Zachodu kolejnymi skrajnościami w filozofii, absolutyzującymi jedną z dwóch przeciwstawionych sobie stron ideowych i alternatyw, jak: racjonalizm-empiryzm, materializm-idealizm, romantyzm-pozytywizm, mistycyzm-scjentyzm, kapitalizm-socjalizm. W rezultacie doprowadziło to do relatywizmu i nihilizmu, które kulminowały w XX-wiecznym egzystencjalizmie i postmodernizmie. Wiek XXI, o ile nie chcemy doprowadzić do ekologicznej katastrofy, powinien być natomiast, jak głosił Skolimowski, wiekiem ekologicznej metanoi - przemiany naszego myślenia, postrzegania świata i postaw na paradygmat ekosystemowy (organiczny, holistyczny). Zdaniem Skolimowskiego ekologia filozoficzna jest filozofią umiaru i zrównoważenia, syntezy, umiaru i klasycznego złotego środka. W wymiarze ekonomiczno-politycznym egzemplifikuje ją zrównoważony rozwój (sustainable development), a w aspekcie stylu życia umiarkowanie, oszczędność i skromność (frugality). Do wartości swojej propozycji eko-etycznej Skolimowski zaliczał również: rewerencję dla życia, odpowiedzialność za życie i środowisko, empatię, różnorodność, ekosprawiedliwość dla wszystkich, afirmację życia, nadzieję (Skolimowski 1993).

Skolimowski był przeciwny zarówno radykalnemu antropocentryzmowi, stanowiącemu bazę materializmu i liberalizmu 
ekonomicznego, jak i przeciwstawiał się radyklanemu nonantropocentryzmowi, który w swym biocentrycznym modelu etycznym przyjęła ekologia głęboka. W aspekcie teologicznym Skolimowski również przyjmował stanowisko pośrednie między teizmem i panteizmem - panenteizm (Waloszczyk 1996), co ontologicznie uzasadnia obecność Sacrum w Świecie, na Ziemi, w przyrodzie i Kosmosie, a nie wyłącznie poza Światem. Uznanie świętości Świata stanowi podstawę dla praktykowania postawy rewerencji - szacunku i autentycznej troski o niego oraz wzięcia odpowiedzialności za jego stan i przyszłość. Usunięcie Sacrum poza obręb świata i ograniczenie go do niematerialnej sfery supranaturalnej, jak ma to miejsce w klasycznej teologii, skutkuje - zdaniem Skolimowskiego - dewastacją przyrody i rosnącym kryzysem ekologicznym, degradacją środowiska bycia człowieka, co przejawia się zarówno w sferze materialnej, jak i w sferze kultury. W obu przypadkach jest to kryzys aksjologiczny, kryzys wartości regulujących stosunek człowieka do siebie, innych ludzi i istot żywych, Świata i Sacrum (Niedek 2001a). Na kryzys w sferze wartości, jako przyczynę kryzysu ekologicznego, wskazał w swojej koncepcji zielonej filozofii również Roger Scruton.

\section{Zielony konserwatyzm Rogera Scrutona}

Roger Scruton (1944-2020) swój wykład na temat Zielonej Filozofii rozpoczyna od negacji globalizmu ekologicznego - działań na rzecz środowiska podejmowanych przez międzynarodowe i globalne instytucje (Scruton 2017). Krytykując globalizm, zwraca się w stronę lokalizmu ekologicznego, uznając, że ekologia lokalna, określana też przez niego Ojkofilą - umiłowaniem domu, najbliższego otoczenia i „małej ojczyzny” - jest właściwą postawą ekologiczną dla człowieka uznającego tradycyjny, konserwatywny system wartości. Przywołuje w ten sposób źródłowy sens greckiego Oikos, oznaczający pierwotnie gospodarstwo i domostwo.

Scruton akceptuje diagnozę złego stanu środowiska naturalnego, a źródeł ekologicznego kryzysu upatruje w zaburzeniu równowagi przyrodniczej spowodowanym działalnością człowieka: „Problem ochrony środowiska postrzegam jako wyrastający z utraty równowagi, do której dochodzi, gdy ludzie przestają pojmować swoje otoczenie jako dom. Ma on wiele przyczyn; jedną z ważniejszych jest złe wykorzystanie prawodawstwa oraz fragmentacja i atomizacja społeczeństwa, zachodzące wówczas, gdy biurokraci biorą sprawy w swoje ręce" (Scruton 2017, 9). Ten filozof konserwatyzmu nie broni bezwarunkowo dotychczasowego dziedzictwa przeszłości, lecz przyznaje wprost, że wiele dotychczasowych praktyk i sposobów działania odpowiada za obecny kryzys ekologiczny: „...gospodarka rynkowa, praworządność, metoda naukowa i religia - są odpowiedzialne za ogromną ekspansję naszego gatunku, a zatem za obecne problemy ekologiczne. To właśnie myśl, że wszystkie nasze adaptacje - biologiczne, społeczne, kulturowe i duchowe - moga być teraz nieskuteczne, jest tak niepokojąca" (Scruton 2017, 66). Dostrzegając wagę współczesnych problemów, jako konserwatysta nie może poddać totalnej krytyce dotychczasowych wzorców działania i wszystkich założeń zachodniej cywilizacji. Poddaje jednak krytycznej refleksji takie fetysze ideologii Zachodu, jak: wolny rynek, problem efektów zewnętrznych i kosztów transakcyjnych, partykularyzm interesów ponadnarodowych korporacji, czy „praworządność" zdegenerowanej biurokracji. Z perspektywy filozofii ekologicznej Scruton wybiera odpowiednią płaszczyznę dyskursu, stwierdzając, że „problemy środowiskowe są problemami moralności, a nie ekonomii" (Scruton 2017, 179). Otwiera to płaszczyznę etyczno-środowiskową dyskusji, co jest o tyle istotne, że na gruncie konserwatyzmu etycznego trudno jest adekwatnie wyartykułować kwestie etyczno-środowiskowe, gdyż problematyka moralna jest w tej optyce zawężana do obszaru relacji człowiek-człowiek (na gruncie religii również do obszaru człowiek-Bóg), 
podczas gdy do specyfiki etyki środowiskowej należy poszerzenie relacji moralnej na obszar bytów pozaludzkich.

Refleksję ekofilozoficzną Scrutona można uznać za poważny namysł konserwatysty nad rzeczywistą i niezbywalną problematyką ekologiczną. Jego zdaniem może ona być polem do współpracy środowisk lewicowych i prawicowych, podobnie jak walka z chorobami cywilizacyjnymi i wynaturzeniami współczesnego społeczeństwa, jakim jest np. konsumpcjonizm: „Jestem przekonany, że sprawa ojkofilii może jeszcze wygrać z życiem sfabrykowanych przyjemności i że wygra, gdy tylko właściwie przedstawimy argumenty. Jeśli uzależniająca kultura wydaje się tak odporna na sprzeciw, to po części z powodu niechęci konserwatystów do tego, by ją potępić - widzą bowiem konsumpcjonizm i technofilię jako postawy zintegrowane $\mathrm{z}$ «rozwiązaniami rynkowymi», które należy chronić przed państwem socjalistycznym. To właśnie w walce z konsumpcjonizmem powinny się zjednoczyć lewica i prawica, zawiązując sojusz na rzecz środowiska, który uzdrowiłby również rozszczepienie naszej cywilizacji. Gdy krytycy ruchu ekologicznego nazywają go lekceważąco „nostalgią" czy „technofobią”, mają rację - tyle że to nie jest krytyka, ale prawdziwe rozpoznanie rzeczy, za którą wszyscy tęsknimy i która tylko czeka, aby ją odzyskać, jeśli nabierzemy otuchy. Tą rzeczą jest ojkofilia" (Scruton 2017, 234).

Pojęcie ojkofilii Scruton przeciwstawia ojkofobii (wyparciu się rodzinnego domu i ojczyzny, w tym miłości do ojczystej przyrody) i technofilii (zatracaniu się w gadżeciarstwie nowinek technologicznych, polegającym na „chęci zapchania domu funkcjonalnymi urządzeniami”). Problemy i wyzwania ekologiczne powinny więc stanowić przestrzeń współpracy i jednoczenia się obrońców środowiska z prawej i lewej strony. Według Scrutona wiele tych działań, podejmowanych z inspiracji konserwatywnych i progresywnych, może być zbieżnych: „W polityce nic nie jest statyczne. Coraz bardziej lewicowi ekolodzy stopniowo odłączają się od prowadzących kampanie organizacji pozarządowych. Wolą pracę na małą skalę, która jednocześnie wspiera i wyraża zrównoważony styl życia. Takie ruchy, jak Miasta Przemian, Low Carbon Communities, Slow Food, parmakultura, przyciągały osoby utożsamiające się z «lewicą». To odwrócenie się od radykalnych rządowych rozwiązań konserwatyści powinni powitać z radością, gdyż obiecuje coś, co potrzeba ekologom obu odłamów, mianowicie dzielenie się problemami i współpracę nad ich rozwiązaniem" (Scruton 2017, 89-90).

\section{Ekologia integralna papieża Franciszka}

Analiza porównawcza eko-filozofii H. Skolimowskiego z innym ujęciem ekofilozoficznym, powstałym na gruncie konserwatywnym, jakim jest ekologia integralna sformułowana przez papieża Franciszka w opublikowanej w 2015 r. encyklice Laudato Si', pokazuje wiele zbieżności pod względem zarówno diagnozy istoty i przyczyn współczesnego kryzysu ekologicznego, jak i w obszarze pozytywnym - propozycji kierunków i rodzajów działań na rzecz przeciwdziałania mu. W aspekcie przyczyn współczesnego kryzysu ekologicznego H. Skolimowski i papież Franciszek formułują zbieżną krytykę współczesnego, liberalnego i egoistycznego materializmu zarówno w wersji kapitalistycznej, jak i socjalistycznej (komunistycznej). Krytyka ta nie ogranicza się tylko do systemu ekonomiczno-politycznego, lecz sięga do ich głębszych, aksjologicznych założeń, bazujących na paradygmacie mechanistycznym (Skolimowski 1993), a w ujęciu papieża Franciszka na - jak to określa - paradygmacie technokratycznym (Franciszek 2015). Do wspólnie krytykowanych przez obydwu myślicieli cech tego - szkodliwego zarówno dla człowieka, jak i środowiska - paradygmatu należy:

- stawianie partykularnych (cząstkowych) interesów wyżej niż interesów całości (społeczeństwa, środowiska, przyszłości);

- traktowanie człowieka jako trybiku i przedmiotu w maszynie świata (go- 
spodarki, korporacji biurokratycznych instytucji, cywilizacji technicznej);

- relatywizm moralny i nihilizm;

- nacisk na wartości praktyczne (utylitarne, pragmatyczne, jak skuteczność, szybkość, rywalizacja, manipulacja) kosztem wartości wewnętrznych i duchowych: piękna, sztuki, miłości, wrażliwości, kontemplacji życia i odczuwania misterium świata.

Wspólną dla papieża Franciszka i profesora Skolimowskiego jest sceptyczna postawa wobec technocentryzmu i wiary w postęp, upatrujących rozwiązania współczesnych problemów (w tym ekologicznych i społecznych) w osiągnięciach techniki i technologii. Krytyce cywilizacji technicznej Skolimowski poświęcił osobny traktat pt. Technika a przeznaczenie człowieka (Skolimowski 1995a). Zarówno Skolimowski, jak i papież Franciszek prezentują stanowisko, że jedynie głęboka, duchowa zmiana świadomości i naszych postaw może otworzyć perspektywy skutecznego rozwiązania współczesnych problemów ekologicznych, gdyż w rzeczywistości nie mają one charakteru technicznego, lecz etyczny, moralny i duchowy (aksjologiczny). Jak pisze Papież: „Technologia powiązana z finansami, aspirująca do bycia jedynym rozwiązaniem problemów, w rzeczywistości nie jest w stanie dostrzec tajemnicy różnorodnych powiązań istniejących między rzeczami i z tego względu niekiedy rozwiązuje jeden problem, tworząc kolejne" (Franciszek 2015, nr 20). Skolimowski wiele uwagi poświęcił analizom nowożytnej nauki i jej dziecka: techniki i technologii. Według niego kluczowy zwrot w pojmowaniu nauki, jako poznania nie dla samego poznania świata, ale w celu jego opanowania dla celów utylitarnych, nastąpił u Francisa Bacona (scientia potentia est - nauka jest mocą). Franciszek, używając określenia „technonauka”, nie odrzuca jednak radykalnie techniki - nie czyni też tego i Skolimowski, uznając potrzebę rozwoju przyjaznej przyrodzie i człowiekowi technologii ekologicznej. Zwraca wszakże uwagę na wiele zagrożeń ze strony dominującego w cywilizacji współczesnej paradygmatu technokratycznego. Podobnie jak Skolimowski i kulturalistyczna filozofia ekologii, kryzys ekologiczny uważa za jeden z objawów głębszego kryzysu spowodowanego redukcjonistycznym paradygmatem technocentrycznym, ujawniającym się również w rzeczywistości społecznej i gospodarczej, w tym w degradacji społeczności i kultury (Niedek 2001b).

Skolimowski uważał, że technika i jej wytwory nie są neutralne moralnie, lecz zakładają i implikują określony system wartości. Papież Franciszek również przyjmuje taki pogląd: „Należy uznać, że przedmioty wytwarzane przez technikę nie są neutralne, ponieważ wpływają na styl życia i ukierunkowują możliwości społeczne zgodnie z interesami określonych grup władzy. Pewne decyzje, które wydają się czysto instrumentalne, są w istocie wyborami odnoszącymi się do typu życia społecznego, jaki ma się rozwijać" (Franciszek 2015, nr 107). Nikt chyba nie zaprzeczy temu, że dominującą determinantą naszego życia jest dziś wszechobecna technika i technologia. Papież, powołując się na Guardiniego, potwierdza, że technika opanowała swoją żelazną logiką niemal całą kulturę, a jej głębokim celem jest nie tyle przynoszenie pożytku i dobrobytu, ile dominowanie i władza - panowanie w nowej strukturze świata - zawładnięcie elementami natury i ludzkiego istnienia (Franciszek 2015, nr 108). Zarówno Skolimowski, jak i Franciszek za wymowny przykład zdominowania ludzkiej przestrzeni życiowej przez technikę uznają współczesną architekturę: „Trudno nam się zatrzymać, aby odzyskać głębię życia. Jeśli architektura odzwierciedla ducha epoki, to megastruktury i seryjne domy wyrażają ducha zglobalizowanej techniki, w której nieustanna nowość produktów łączy się z ciążącą nudą. Nie gódźmy się z tym i nie rezygnujmy ze stawiania sobie pytań o sens i cel wszystkich rzeczy. W przeciwnym razie usprawiedliwimy stan faktyczny i będziemy potrzebowali więcej namiastek, aby przetrwać w tej pustce" (Franciszek 2015, nr 113). 


\section{Ekologiczny styl życia}

Podrozdział ostatniego rozdziału Laudato si' pt. „Edukacja i duchowość ekologiczna” poświęcony został potrzebie kształtowania i upowszechnienia nowego stylu życia. W definiowaniu go papież Franciszek zasadniczo powiela postulaty środowisk ekologicznych: ograniczanie i eliminacja konsumpcjonizmu, minimalizm, przeciwdziałanie powstawaniu odpadów, ponowne używanie produktów, recykling, promowanie ekoedukacji (dzieci, dorosłych, rodzin) i etyki ekologicznej (w tym wśród dzieci), obywatelskie zaangażowanie ekologiczne, aktywność w ruchu konsumenckim, wspólnotach lokalnych. Franciszek zachęca też do rozwijania lokalnych inicjatyw ekonomii społecznej i spółdzielczości, stanowiących alternatywę dla liberalnego i globalnego korporacjonizmu ekonomicznego (Łętocha 2016). Skolimowski i Papież afirmują potrzebę trwałego i zrównoważonego rozwoju. Inaczej jednak niż Scruton widzą potrzebę współdziałania i solidarności na rzecz środowiska, także na poziomie międzynarodowym i globalnym. Nie dostrzegają też sprzeczności pomiędzy ekologią lokalną i globalną, lecz naturalne, spójne przejście: „[...] ekologia społeczna musi być instytucjonalna i stopniowo osiągać różne wymiary, począwszy od podstawowej grupy społecznej, od rodziny, przez społeczność lokalną i naród, aż po życie międzynarodowe" (Franciszek 2015, nr 141). Tak jak naturalnym i pierwotnym miejscem życia człowieka jest dom rodzinny, miejscem życia narodu jest państwo, tak domem ludzkości jest Ziemia. Budowanie przestrzeni konsiliencji (zgody) ekologicznej zarówno pomiędzy naukami przyrodniczymi i humanistycznymi, jak i między stanowiskami progresywnymi i konserwatywnymi, wymaga refleksji metafilozoficznej i aksjologicznej z obszaru filozofii kultury. Obszary te prezentuje tabela 1 i 2.

\section{Podsumowanie}

Skolimowski, Scruton i papież Franciszek dostrzegają unifikujące znaczenie problematyki ekologicznej, która powinna jednoczyć prawą i lewą stronę filozofii, światopoglądów, społeczeństwa i polityki. Właściwą przestrzeń do praktykowania postaw ekologicznych i prowadzenia zrównoważonego, osiadłego stylu życia Scruton upatruje na wsi. Chodzi mu o tradycyjną wieś, niepozbawioną tradycyjnej kultury, różnorodności biologicznej i bogactwa krajobrazu, do których zubożenia przyczyniły się procesy modernizacyjne oraz przemysłowe i intensywne rolnictwo. Ostatnim tekstem Skolimowskiego, jaki napisał, było wprowadzenie do książki Sir Juliana Rose W obronie $\dot{z} y c i a$, w którym rekomendował rolnictwo

Tabela 1. Różnice w podejściach ekofilozoficznych H. Skolimowskiego, R. Scrutona, P. Franciszka (opracowanie własne)

\begin{tabular}{llll}
\hline Aspekt & $\begin{array}{l}\text { Eko-filozofia } \\
\text { H.Skolimowskiego }\end{array}$ & $\begin{array}{l}\text { Zielona filozofia } \\
\text { R.Scrutona }\end{array}$ & $\begin{array}{l}\text { Ekologia integralna papieża } \\
\text { Franciszka }\end{array}$ \\
\hline Perspektywa poznawcza & Holizm, umysł partycypujący & Lokalizm & $\begin{array}{l}\text { Perspektywa religijna } \\
\text { (teocentryczna) }\end{array}$ \\
\hline Baza światopoglądowa & $\begin{array}{l}\text { Eko-kosmologiczna wizja } \\
\text { ewolucji } \\
\text { (H. Bergson, P.T. de Chardin, }\end{array}$ & Konserwatyzm & $\begin{array}{l}\text { Teologia i antropologia } \\
\text { chrześcijańska }\end{array}$ \\
& A.N. Whitehead) & & \\
\hline $\begin{array}{l}\text { Przeciwdziałanie } \\
\text { kryzysowi ekologicznemuia }\end{array}$ & Metano & Ojkofilia & Ekologiczne nawrócenie \\
\hline Wartości & Eko-etyka & Zakorzenienie we & Proekologiczna interpretacja Pisma \\
& & $\begin{array}{l}\text { wspólnocie, tożsamość, } \\
\text { tradycja }\end{array}$ & Św., podejście św. Franciszka z Asyżu \\
\hline
\end{tabular}


Tabela 2. Podobieństwa w ujęciach ekofilozoficznych H. Skolimowskiego, R. Scrutona, papieża Franciszka (opracowanie własne)

\begin{tabular}{llll}
\hline Aspekt & $\begin{array}{l}\text { Eko-filozofia } \\
\text { H. Skolimowskiego }\end{array}$ & $\begin{array}{l}\text { Zielona filozofia } \\
\text { R. Scrutona }\end{array}$ & $\begin{array}{l}\text { Ekologia integralna papieża } \\
\text { Franciszka }\end{array}$ \\
\hline $\begin{array}{l}\text { Diagnoza przyczyn } \\
\text { kryzysu ekologicznego }\end{array}$ & $\begin{array}{l}\text { Mechanicyzm } \\
\text { („Bożek Mechanos”) }\end{array}$ & Technofilia i ojkofobia & $\begin{array}{l}\text { Paradygmat technokratyczny } \\
\text { (technonauka i technokultura) }\end{array}$ \\
\cline { 2 - 3 } & \begin{tabular}{l} 
Świadomośćzłego stanu środowiska (kryzysu ekologicznego) \\
\cline { 2 - 3 }
\end{tabular} & $\begin{array}{l}\text { Krytyka materializmu kapitalistycznego i socjalistycznego, polityki i gospodarki liberalnej (mitu } \\
\text { postępu i egoizmu rynkowego) }\end{array}$ \\
\cline { 2 - 3 } & Krytyka relatywizmu moralnego i nihilizmu \\
\cline { 2 - 3 } & $\begin{array}{l}\text { Krytyka fundamentalizmu ekologicznego (antyantropocentryzmu ekologii głębokiej } \\
\text { i radykalnego ekologizmu) }\end{array}$ \\
\hline Wartości & Antymaterializm, antykonsumpcjonizm, antybiurokratyzm \\
\cline { 2 - 3 } & $\begin{array}{l}\text { Znaczenie duchowości i sacrum w kształtowaniu postaw pozwalających zachować środowisko } \\
\text { w odpowiednim stanie dla nas i przyszłych pokoleń }\end{array}$ \\
\hline Działanie & Potrzeba aktywnego działania na rzecz środowiska, zrównoważony rozwój \\
\cline { 2 - 3 } & Uznanie problematyki ekologicznej za problem moralny \\
\hline
\end{tabular}

ekologiczne jako przykład praktycznego zastosowania ekologicznego holizmu w podejściu do przyrody (Rose 2014). J. Rose, akceptując eko-filozofię jako ideowe zaplecze proekologicznego pragmatyzmu, wskazał na potrzebą kultywowania ekologii praktycznej związanej z powrotem do naturalnego rolnictwa, krótkich łańcuchów dostaw żywości i eliminowania pośredników handlowych w dostępie do niej. W rolnictwie ekologicznym dobrostan zwierząt, obok dbania o żyzność gleby, równowagę paszowo-nawozową i płodozmian, są kluczowymi zasadami zapewniającymi zrównoważenie (sustainability) i trwałość upraw i hodowli ${ }^{4}$. Rolnictwo ekologiczne i zrównoważony rozwój obszarów wiejskich jest praktyczną przestrzenią kultywowania wartości ekologicznych, mądrości ekologicznej i postawy ojkofilii Scrutona. W ekologicznym systemie hodowli zwierząt znika przyczyna sporu związana z ich dobrostanem, jaką wzbudziła w 2020 r. w Polsce projektowana ustawa o ochronie zwierząt. Ekologizacja rolnictwa, jako podstawowego gospodarczo systemu produkcji pierwotnej, wydaje się więc

4 Propagatorem eko-filozofii w rolnictwie był w latach 9o. XX w. inicjator rolnictwa ekologicznego w Polsce prof. dr hab. Mieczysław Górny (Górny 1992). kierunkiem równie potrzebnym, co ekologizacja światopoglądowa na bazie wspólnych i uniwersalnych wartości ekologicznych, do których należą: życie, zdrowie, rozwój, zrównoważenie.

\section{Bibliografia}

Bonenberg, Marek. 1992. Etyka środowiskowa: założenia i kierunki. Kraków: Zakład Etyki w Instytucie Filozofii Uniwersytetu Jagiellońskiego. Brundtland, Gro Harlem. 1987. Our Common Future. Oxford: Oxford University Press.

Ferry, Luc. 1995. Nowy tad ekologiczny. Drzewo, zwierze $i$ czlowiek. Warszawa: Centrum Uniwersalizmu przy Uniwersytecie Warszawskim. Ferry, Luc, and Claude Capelier. 2016. Filozofia. Najpiękniejsza historia. Warszawa: Wydawnictwo Czarna Owca.

Franciszek, Ojciec Święty. 2015. Encyklika Laudato Si'. Wtrosce o wspólny dom. Kraków Wydawnictwo M. Gliński, Piotr. 1994. Polscy Zieloni. Ruch społeczny w okresie przemian. Warszawa: IFiS PAN.

Górny, Mieczysław. 1992. Ekofilozofia rolnictwa. Krosno: Centrum Edukacji Ekologicznej Wsi.

Gruhl, Herbert. 1976. Ein Planet wird geplündert. Die Schreckensbilanz unserer Politik. Frankfurt a. M.: S. Fischer.

Hoły-Łuczaj, Magdalena. 2018. Radykalny nonantropocentryzm. Martin Heidegger i ekologia 
głęboka. Warszawa: Wydawnictwo Uniwersytetu Warszawskiego.

Kiełczewski, Dariusz. 2001. Ekologia społeczna. Białystok: Wydawnictwo Ekonomia i Środowisko.

Kołakowska, Agnieszka. 2018. Konserwatysta wobec wspótczesnych ruchów ekologicznych. Dostęp 22.12.2020. https://teologiapolityczna. pl/agnieszka-kolakowska-konserwatysta-wobecwspolczesnych-ruchow-ekologicznych.

Łętocha, Rafał. 2016. Ekonomia wspótdziałania. Katolicka nauka społeczna wobec wyzwań globalnego kapitalizmu. Kraków: Wydawnictwo Uniwersytetu Jagiellońskiego.

Meadows, Donella, Dennis Meadows, Jorgen Randers, and William Behrens III. 1972. The Limits to Growth. New York: Universe Books.

Najder-Stefaniak, Krystyna. 2013. Wprowadzenie do ekofilozofii. Warszawa: Wydawnictwo SGGW.

Niedek, Mikołaj. 2001a. „Filozofia ekologiczna jako filozofia kultury." ARCHEUS. Studia $z$ Bioetyki i Antropologii Filozoficznej 2: 45-56.

Niedek, Mikołaj. 2001b. „Kryzys ekologiczny jako kryzys kultury." Humanistyka i Przyrodoznawstwo 7: 111-122.

Papuziński, Andrzej, i Zbigniew Hull. 2001. Wokót eko-filozofii. Ksiega jubileuszowa ofiarowana Profesorowi Henrykowi Skolimowskiemu dla uczczenia siedemdziesięciolecia urodzin. Bydgoszcz: Wydawnictwo Akademii Bydgoskiej im. Kazimierza Wielkiego.

Papuziński, Andrzej. 1999. Wprowadzenie do filozoficznych problemów ekologii. Bydgoszcz:
Wydawnictwo Uczelniane Wyższej Szkoły Pedagogicznej.

Rose, Julian. 2014. W obronie życia. Pragmatyczne propozycje dla cierpiacej planety. Gdynia: Genesis. Scruton, Roger. 2017. Zielona filozofia. Jak poważnie myśleć o naszej planecie. Poznań: Zysk i S-ka.

Skolimowski, Henryk. 1967. Polish Analytical Philosophy: A Survey and a Comparison with British Analytical Philosophy. New York: Humanities Press.

Skolimowski, Henryk. 1974. Zmierzch światopogladu naukowego. London: Odnowa.

Skolimowski, Henryk. 1977. Ecological humanism. Lewes: Gryphon Press.

Skolimowski, Henryk. 1993. Filozofia żyjaca: ekofilozofia jako drzewo życia. Warszawa: Pusty Obłok. Skolimowski, Henryk. 1995a. Technika a przeznaczenie człowieka. Warszawa: Ethos.

Skolimowski, Henryk. 1995b. The Participatory Mind: A New Theory of Knowledge and of the Universe. London: Arkana.

Skolimowski, Henryk. 1999. Wizje nowego Millennium. Kraków: Wydawnictwo EJB.

Thant, U Sithu. 1969. The problems of human environment. Resolution UN nr 2398. Accessed January 14, 2021. https://undocs.org/en/A/ RES/2398(XXIII).

Waloszczyk, Konrad. 1996. Kryzys ekologiczny w świetle ekofilozofii. Łódź: Wydawnictwo Politechniki Łódzkiej. 